\title{
1970-Economy in Transition
}

\author{
by NORMAN N. BOWSHER
}

NFLATION gradually intensified in this country from late 1964 to early 1970, and expectations of future inflation were progressively revised upward. The interruptions to output and the inequities caused by redistributions of wealth and income resulting from the inflation and inflationary expectations became a serious domestic economic problem.

During 1970 inflation remained strong and pervasive, but the rate of price advance began receding

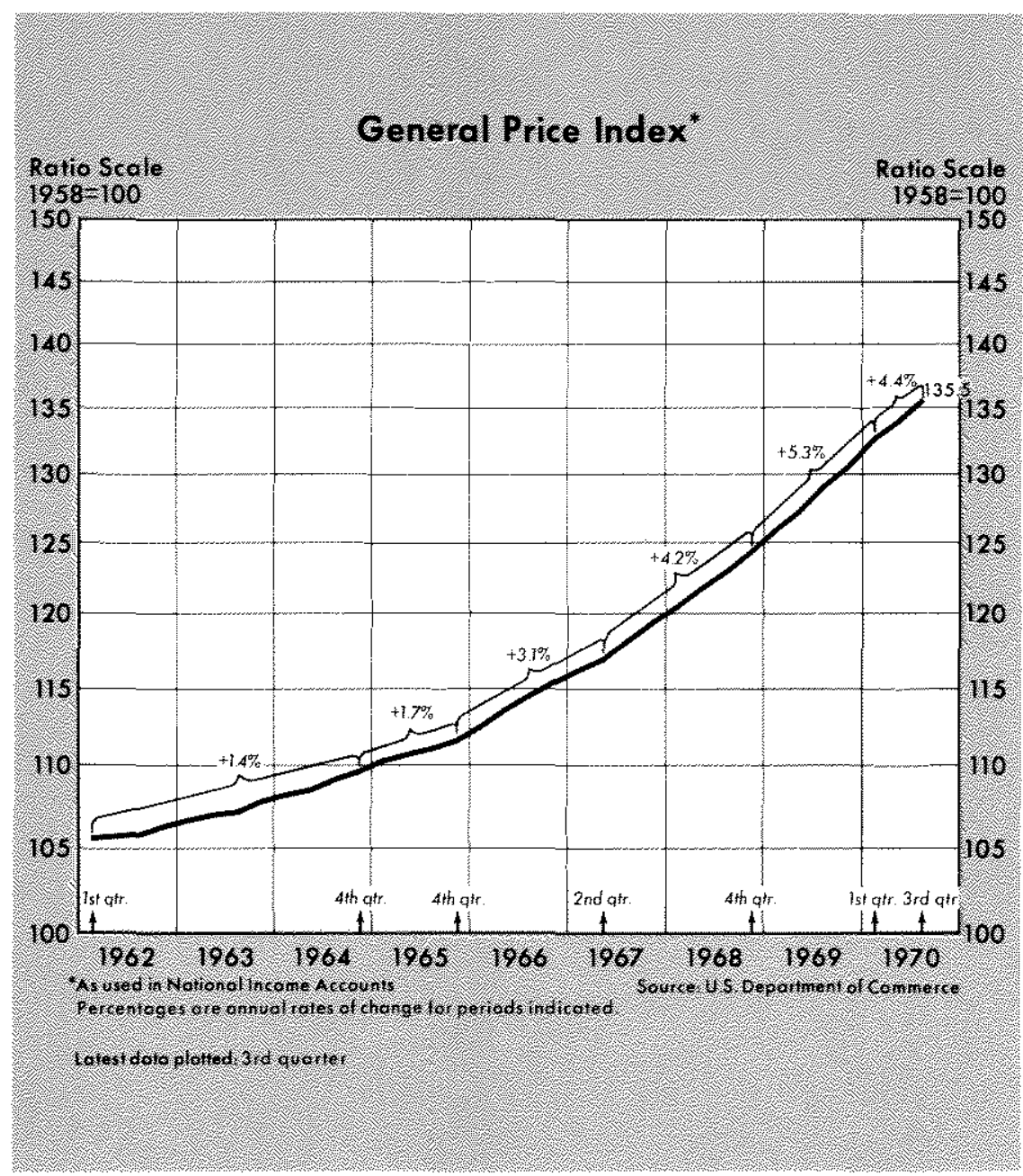

slowly. Inflation has become imbedded in thinking, expectations, policies, contracts, and regulations. This article: 1) points out some of the effects of inflation; 2) reviews the period during the inflation build-up; 3) examines actions taken to resist inflation before 1970 ; 4) discusses alternative courses of monetary action for 1970 ; 5) traces the monetary actions taken; 6) analyzes spending, production and price developments in 1970; and 7) presents three courses of monetary action for 1971.

\section{Lifects of Indtation}

Inflation is a rise in the average level of prices or, stated in another way, a decline in the purchasing power of money. ${ }^{1}$ Because of the key roles money and money-denominated assets play, an unanticipated decline in the value of money has many effects on production and distribution. It affects holders of money adversely, reduces the relative value of outstanding bonds, mortgages, savings accounts, and other dollardenominated assets, while giving windfall gains to debtors. Those on pensions and others having relatively fixed incomes have less real buying power with inflation.

${ }^{1}$ All price increases are not inflationary. In a dynamic growing economy with overall price stability, some prices rise while others decline. Factors affecting individual prices include advances in technology, changes in resource availability, amounts of capital invested, and changing consumer tastes and preferences. Movements of individual prices serve the very useful functions of equating supply and demand for individual products and services and of allocating the nation's resources. Attacking inflation by controlling individual prices does not get at the crux of the problem. Such a policy ustally creates inequities and shortages and tends to stifle growth and progress. 
Just as there are costs and inequities of adjusting to a higher rate of inflation, there are costs and inequities involved in adjusting to a rate of inflation lower than anticipated. Contracts and other commitments made on the expectation of continued inflation become more burdensome to fulfill if inflation is less than anticipated. When excessive spending is dampened, many prices continue to move upward as an adjustment to past excesses and inequities, causing declines in production and unemployment.

The current inflation is likely to have pervasive effects on redistributing income and wealth for a long time. Costs of adjusting to inflation can be minimized if the rate of inflation is stabilized for a prolonged period. If inflation were stabilized at a zero rate, no adjustments would be required to protect against a changing purchasing power of money.

\section{Accolertating Inhation}

Total spending on goods and services rose at an average 8 per cent annual rate from late 1964 to the fall of 1969. Since there was little available excess capacity, increases in real output were constrained by the growth in the nation's capacity to produce. The rise in spending was roughly double the estimated rate of real growth, and prices were gradually bid up until, in 1969, overall prices rose more than 5 per cent.

The economy received many expansive shocks beginning in 1964. Expenditures of the Federal Government rose progressively relative to receipts until mid-1968. Income tax rates were reduced in early 1964 to eliminate a "fiscal drag" and get the economy moving. Reflecting the war in Vietnam, defense outlays of the Govermment, which had risen at a 1.3 per cent annual rate from 1957 to 1964 (national income accounts basis), increased at a 14 per cent rate from 1964 to mid-1968. Growth in nondefense outlays of the Federal Government was also stepped up from the 9.6 per cent rate from 1957 to 1964 to a 12 per cent rate from 1964 to mid-1968. ${ }^{2}$

Studies at this Bank indicate that these fiscal actions alone were not sufficient to accomplish the rapid growth in total spending and the acceleration of inflation. Such Government actions may reallocate income and resources and may effect the trend growth in

${ }^{2} \mathrm{~A}$ summary measure of the Government's budgetary influm ence on the economy is provided by the high-employment budget (a concept which eliminates the effect of changing levels of business activity on the budget). This measure shifted dramatically from a $\$ 13$ billion surplus in 1963 to a $\$ 14$ billion annual rate of deficit in the first half of 1968 .

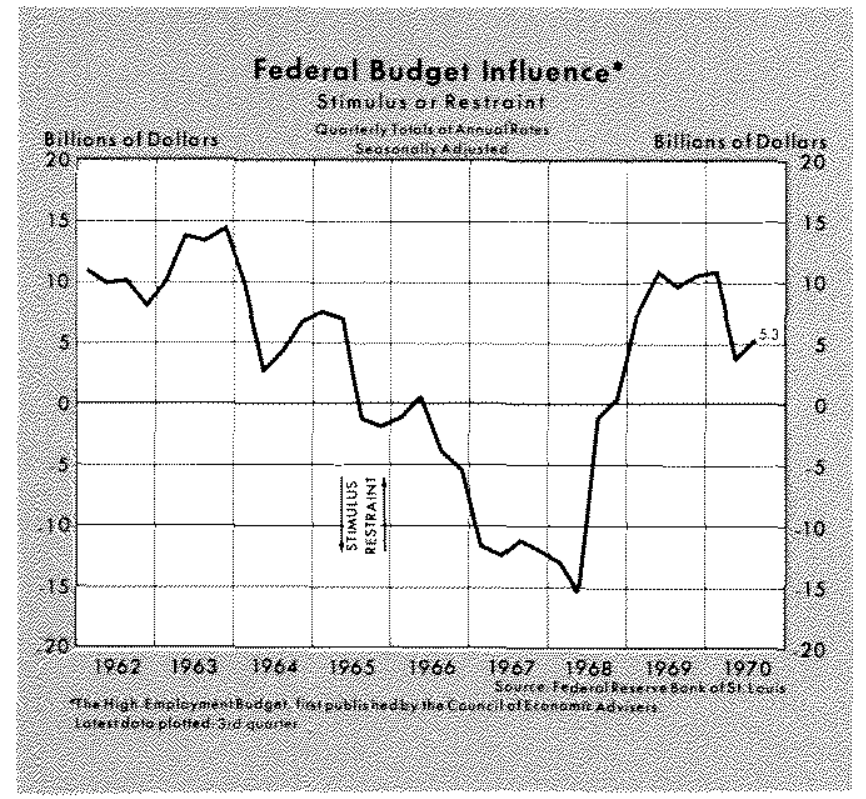

capacity. Initially they also have some influence on total spending. However, the aggregate influence of the Government budget on total spending is relatively small if the resulting deficits or surpluses are financed by the public out of planned saving rather than accompanied by changes in the money stock. ${ }^{3}$

Monetary actions were also very expansive beginning in late 1964. By supplying more money than the public desired to hold, given current levels of income, wealth, and interest rates, the public's demand for other financial assets and for goods and services was stimulated. From late 1964 to early 1969 money rose at a 5.3 per cent average rate, up from a 3 per cent rate earlier in the decade and a 2 per cent rate in the Fifties. Except for the ninemonth period of restraint from the spring of 1966 to early 1967, monetary expansion was at a very rapid 7 per cent average rate.

\section{Acthons Taken Before 1970 to Pextst Inlation}

As the inflation problem built up, the Government became concemed and took a number of actions designed to restrain it. Unfortunately, many of the actions were insufficient in magnitude, were based on

$3^{34}$ Monetary and Fiscal Actions: A Test of Their Relative Importance in Economic Stabilization," this Review (November 1968), pp. 11-24, and "Monetary and Fiscal Infuences on Economic Activity - The Historical Evidence," this Review (November 1969), pp. 5-24.

Effects of changes in Government activities tend to be crowded out by opposite movements in private spending when the Government finances its deficits with increased debt to the public. See "The Crowding Out of Private Expenditures by Fiscal Actions," this Review (October 1970), pp. $12-24$ 
poor economic analysis, or had only delayed effects. Thus they proved to be largely ineffective before 1970. Chief actions presumed and intended to be anti-inflationary were using moral suasion to moderate wage and price increases, permitting higher interest rates, regulating credit, raising tax rates, reducing the rate of growth of Government spending, and finally, slowing the growth in money.

Moral Suasion - Before the acceleration of inflation began in the mid-Sixties, the President's Council of Economic Advisers had presented a set of guideposts for labor and management. The guideposts and other appeals to the public were not effective in holding down wages or prices when pressures became strong. Workers and businessmen would not forgo returns which were available to them. Even if they had, the economy would have become less efficient, incentives would have been reduced, shortages would have developed, and resources would not have been attracted into areas of greatest demand.

Interest Rates-Market interest rates increased greatly from 1964 through 1969. Yields on highest-

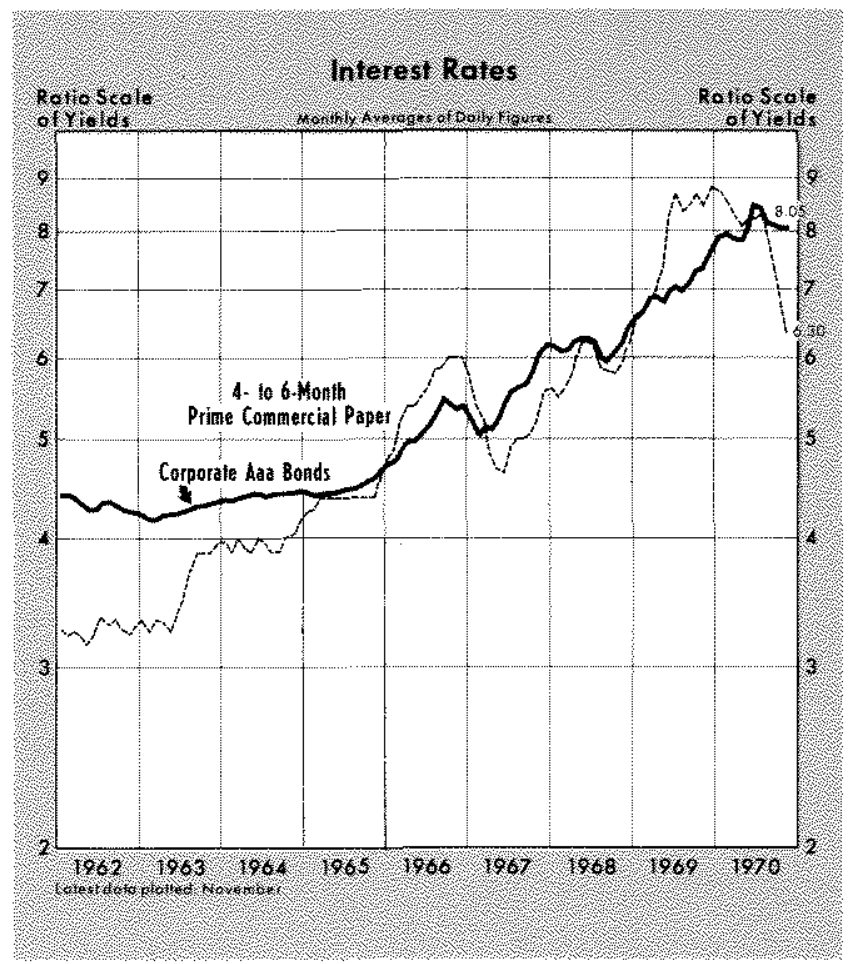

grade seasoned corporate bonds, for example, went up dramatically from 4.5 per cent in the early Sixties to nearly 8 per cent in late 1969. It was thought that

4Wages were to be raised no faster than the national trend of productivity growth (estimated at about 3 per cent a year), and prices were to be established so as not to raise profit margins. the higher rates would restrain the expansion of investment and other spending while stimulating saving.

The rise in interest rates was in response to a great demand for loan funds by both the Government and private sectors. The private sector demand derived from the rapid growth in total spending and anticipations of inflation. With expected inflation, borrowers were willing to pay higher rates to buy plants and equipment because these items were likely to cost more later ${ }^{5}$ Rapid monetary expansion resulted, in part, from the central bank attempting to moderate interest rate increases in the short rum. But the rapid monetary expansion, by stimulating total spending and thereby increasing inflation, led to still greater demands for credit and higher interest rates than would have occurred without such monetary expansion.

Credit Regulation - Regulation $Q$ was administered on the basis of a belief that it would help limit inflation. This Regulation, which originated in 1935 under quite different circumstances, was used to keep the rates that banks were permitted to pay on time deposits below market rates during most of 1969 . As a result time deposits in commercial banks fell 5 per cent in the year, after rising at a 14 per cent anmual rate in 1967 and 1968. Largely as a result, total credit extended by commercial banks rose only 3 per cent during 1969 , following an 11 per cent rate in the two previous years.

The total supply of funds, however, was not diminished; they flowed from supplier to ultimate user through other channels, such as direct loans, commercial paper, and the Eurodollar market. ${ }^{6}$ Regulation $Q$ probably had little or no effect on either total credit extended or total spending. Yet, by diverting funds through alternative routes, inefficiencies and inequities developed. Homebuyers, small businesses, and consumers, who must rely on local financial institutions to obtain credit, were at a disadvantage. Large businesses which could obtain funds in central money markets received more funds and probm ably at lower rates than in the absence of the disintermediation. Small savers were penalized by the low regulated rates received, while larger lenders who have more altematives received higher retums.

\footnotetext{
5"Interest Rates and Price Level Changes, 1952-69," this Review (December 1969), pp. 18-38.

GIn suspending the ceiling on 30- to 89-day large certificates of deposit the Board of Governors noted on June 23, 1970 that an expected increase ". . . in bank loans would not constitute an increase in total credit flows, to the extent that they simply represented a transfer of borrowings from other financial avenues, , . . Federal Reserve Bulletin (July 1970), p. 605 .
} 
Fiscal Actions - The Revenue and Expenditure Control Act was signed into law on June 28, 1968. The major features of the Act were a 10 per cent surtax designed to reduce the amount of disposable income and thereby slow private spending, and a requirement that the growth of Government spending be restricted. Federal outlays in the national income accounts budget rose at a 6 per cent amual rate in the last half of 1.968 and in 1969 , compared with a 13 per cent trend rate from late 1964 to mid-1968. As a result of these actions, growth in total spending was expected to slow by some multiple, placing immediate downward pressure on prices.

These fiscal actions of mid-1968 did not produce the results expected by their sponsors. Excessive growth in total spending continued at only a slightly reduced rate. Slower growth in spending by the Federal Government was largely offset by greater outlays of those who were able to attract the funds formerly flowing to the Government to finance its deficits.

Monetary Actions - Growth in the nation's money stock was slowed markedly in early 1969 in another attempt to reduce the inflationary surge. Following a rapid 7.6 per cent annual rate of money growth during 1967 and 1968, growth in money slowed in the first seven months of 1969 to a 5.1 per cent rate, and to a 1.2 per cent rate from July to February 1970 . With the money stock growing at a slower rate than the

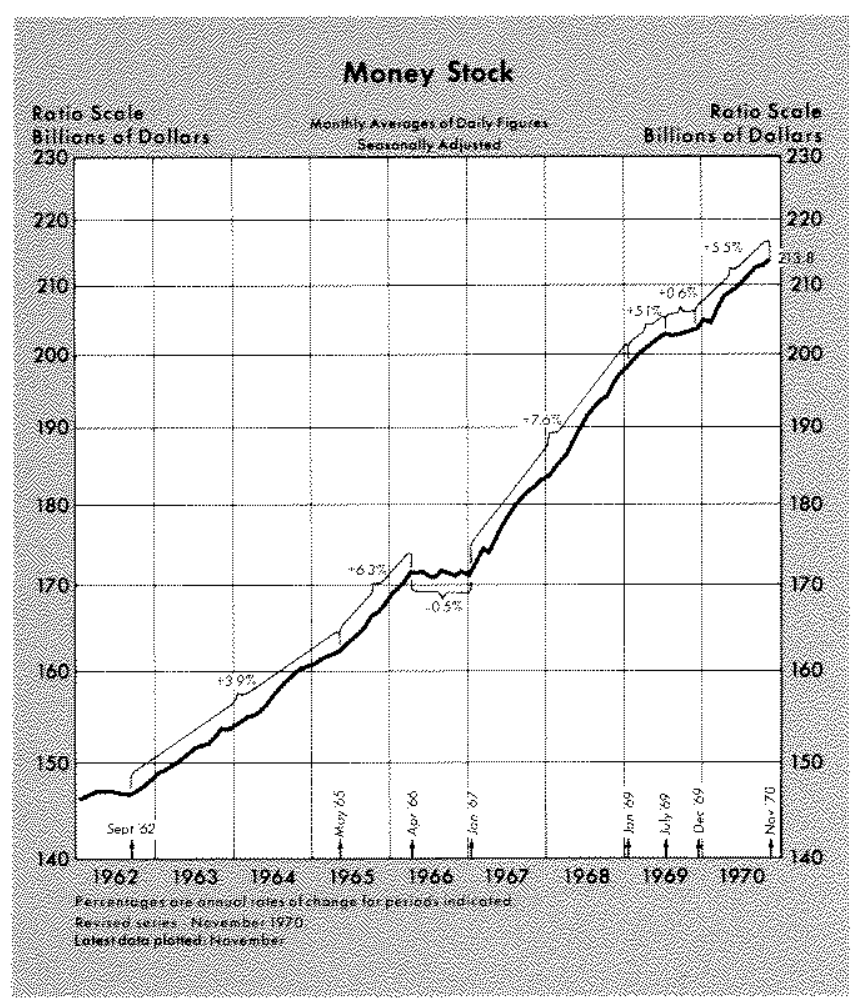

demand for money, spending was expected to slow as businesses and consumers attempted to conserve cash balances.

As usually occurs after a change in the growth trend of money, spending continued to be influenced primarily by the previous trend of money growth for about six months. Hence, spending continued to rise excessively until the early fall of 1969, and inflationary pressures intensified despite the monetary restraint. Later in the year, total spending slowed, but prices continued to rise in delayed response to the previous excessive spending. Despite the actions taken, the upward surge of prices continued to accelerate through 1969.

\section{Polly Alternatives at the Beginng of 1070}

As 1970 began, the economic situation was suffering greatly from the fiscal and monetary actions of 1965 through 1968. The rate of overall price increase was about 5.5 per cent a year at the end of 1969 , after accelerating for five years. Real production was not expanding, unemployment was rising slightly, and corporate profits were declining. Both bond and stock prices were lower than a year earlier. On the favorable side, the battle against inflation had begun to show the first signs of success. The excess demand, which was the major causal link to inflation, had been moderated.

The crucial consideration for the nation in the com" ing year was to determine how rapidly the price effect of the past excesses could and should be extinguished. If restrictive monetary actions were aggressively pursued, the rise in total demand for goods and services might slow rapidly, and inflationary pressures might be extinguished sooner than otherwise. However, the transitional costs in terms of lower production, employment, and incomes would be severe, and the temptation would be strong to restimulate the economy before the task was completed, as had been done in 1967.

On the other hand, if demand grew so rapidly as to permit growth in production, employment, and real incomes to continue at near their long-run optimal trends, moderation of inflation might never be achieved. In such a case, the country would continue for a prolonged period to suffer inefficiencies and inequities caused by a continuous erosion of the value of the dollar. Some middle course seemed more advisable than either a quick vigorous correction or the toleration of endless, and possibly increasing, inflation. 
Table Simulation of Allernotive gates of Monetary Expanston at the Beginning of 1970

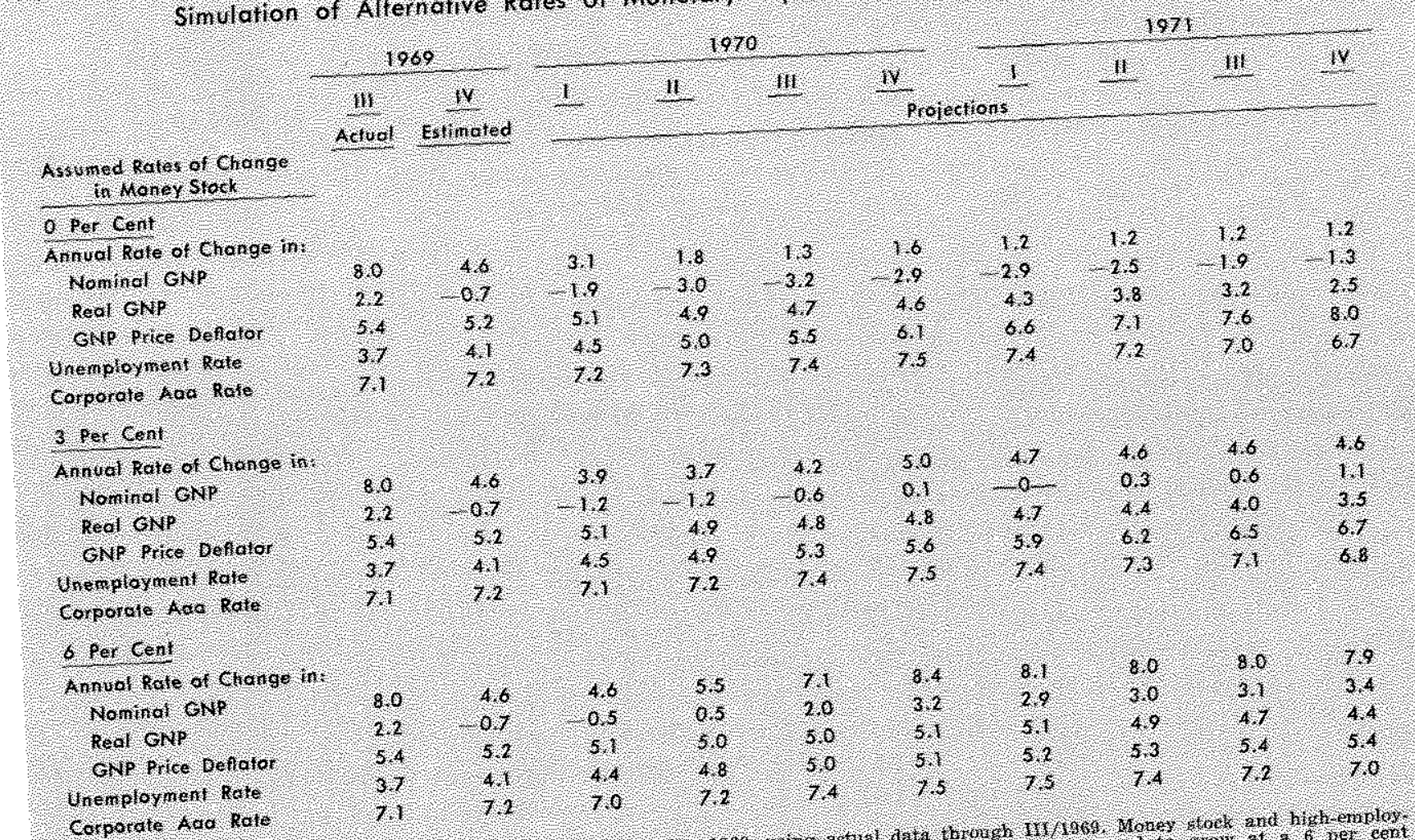

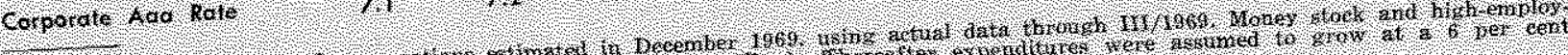

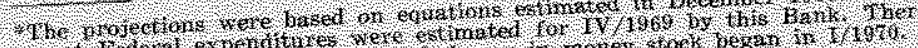

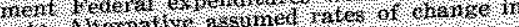

This Bank at the beginning of the year simulated The effects on the economy of three alternative courses of monetary action. These simulations were prepared using the Bank's model, and assuming Federal Govermment expenditures would grow 6 per cent in the year. $^{\mathrm{T}}$

One test assumed a slight tightening of the restrictive monetary actions which had been followed since mid-1969, that is, holding the money stock unchanged. The model indicated that this would cause a significant recession in 1970 and 1971 (see table). Total spending would rise only slightly, output would decline at a 2 or 3 per cent annual rate, and unemploy. ment would move up to over 6 per cent by the end of 1970 and to about 8 per cent by the end of 1971 . Because the imbedded inflation was strong, the rate of price increase would slow only gradually. The model indicated that prices might still be going up at about a 4.5 per cent rate in late 1970 and at a 2.5

FFor a discussion of the model see "A Monetarist Model For Stabilization," this Review (April 1970), pp. 7-25. Econome Stabilization, the Revis model are presented in Current projections based on this mole whe when is available the "Quarterly Economic Trom

per cent rate in late 1971 . With the continued rapid rate of price increase, long-term interest rates were projected to remain high during 1970 .

A second test assumed a less restrictive 3 per cent annual growth of money (similar to the trend since 1953). The simulation indicated that the econonic adjustment would be less severe but also less progress against inflation could be expected. Under such a policy, total spending was projected to rise at a 4 to 5 per cent rate during 1970 and 1971 . Over the two year span, price increases might slow to a 3.5 per cent rate while unemployment might rise to about 6.7 per cent of the labor force.

A third test assumed a still more expansive policy 6 per cent annual rate of increase in money). This indicated a more expansive economy but with only slight downward pressure on inflation. The rise in total spending was projected to accelerate during 1970 to about an 8 per cent rate and continue at that rate during 1971. Production would quickly begin expanding, reaching about a 3 per cent rate of growth in late 1970 and a slightly higher pace a year later. Unemployment would rise to just over 5 per 
cent in late 1970 and to about 5.5 per cent in late 1971. After two years of such a policy, the simulation indicated the rise in prices would slow only gradually from the 5.3 per cent rate in late 1969 to about a 5 per cent rate in late 1970 and to about a 4.5 per cent rate in late 1971.

The choice was difficult. No policy alternative promised a quick, painless elimination of inflation. Fewer real goods and services would be available because of lost production and unemployment, and pain caused by inequities and inefficiencies of inflation would continue. One lesson from the experience was obvious; more care should be taken in the future to avoid such mistakes as those of 1965 through 1968 which generated the strong inflationary momentum.

\section{Monetavy Achons Duthy 1970}

Early in 1970 the Federal Reserve System adopted a more expansive policy and began placing more emphasis on monetary aggregates in policy formulation and implementation. Late in 1969 the System's Open Market Committee (the chief policymaking group) had directed the operating manager to maintain the prevailing firm conditions in money markets. ${ }^{8}$ This was a continuation of the policy which had resulted in the slow growth of the money supply beginning in July 1969.

At the January 1970 meeting a slight easing of policy was adopted, and the manager was requested, among other things, to seek a modest growth in money and bank credit. At the February meeting (and most subsequent meetings for which directives have been made public, after about a three-month lag) the manager was requested to seek a moderate growth in money and bank credit. ${ }^{10}$ The word "moderate" presumably implied more expansion than "modest."

The word "moderate" in the directive was interpreted to mean different rates of expansion from one meeting to another. In general, policy in terms of money was initially to seek about a 3 per cent annual rate of increase; at the May 5 meeting, the target was raised to 4 per cent. ${ }^{11}$ During the late Spring and early Summer when fears of financial panic arose with the declines in security prices, the Committee temporarily agreed that operations should be adjusted as necessary to moderate unusual pressures in financial markets, should they develop. The money mar-

8Federal Reserve Bulletin, March 1970, pp. 273 and 278.

9Federal Reserve Bulletin, April 1970, p. 339.

10 Federal Reserve Bulletin, May 1970, p. 442.

11 Federal Reserve Bulletin, August 1970, p. 631. ket conditions specified in the meeting of May 26 were thought to be consistent with a 7 per cent rate of money expansion from March to June. ${ }^{12}$ At the meeting of June 23, the Committee adopted a target rate of about a 5 per cent growth rate in the money supply from June to September. ${ }^{13}$ This target was reaffimed at meetings of July 21 and August 18 (the last released record). ${ }^{14}$

The directives, however, were not without ambiguity. Money was not the only aggregate to be controlled; the Manager was also directed to obtain a moderate growth in bank credit. Because of the reintermediation of time deposits following relaxations of Regulation $Q$ in January and in June and declines in market interest rates, bank credit rose very rapidly. It became clear that the System could not count on obtaining the specific objectives with respect to both money and bank credit. The primary emphasis was placed on the money objective in the directive of August 18. The bank credit effects of the reintermediation were viewed as a substitution of bank credit for other credit.

Even though the Committec sought a given rate of growth in money, it was not intended that the manager was to seek this trend rate each day, each week, or even each month. The reason for not rigidly applying the aggregate guide in the short run was to avoid the gyrations in interest rates that was thought might be produced by a strict adherence to the aggregates. In these shorter periods the manager was to operate, as previously, with an eye to money market conditions. The conditions selected were those thought to be consistent with a growth in the aggregates at the desired rate over a period of about three months. Whenever the aggregates appeared to be deviating significantly from the desired path, the manager was to permit changes in the money market conditions to develop with an objective of getting the aggregates on course. This procedure was not precise, but largely a trial and error approach. Also, money maxket conditions were not always used merely as a means to obtain the desired growth rate in money; at times money market conditions became an end in themselves to be considered along with the aggregate targets.

From December 1969 to the four weeks ending December 4, 1970 the money stock rose at a 5.5 per

1.2Federal Reserve Bulletin, September 1970, pp. 711-13.

13ibid., pp. 717-19.

${ }^{4}$ Federal Reserve Bulletins, October 1970, pp. 762-3 and November 1970 , p. 820 . 


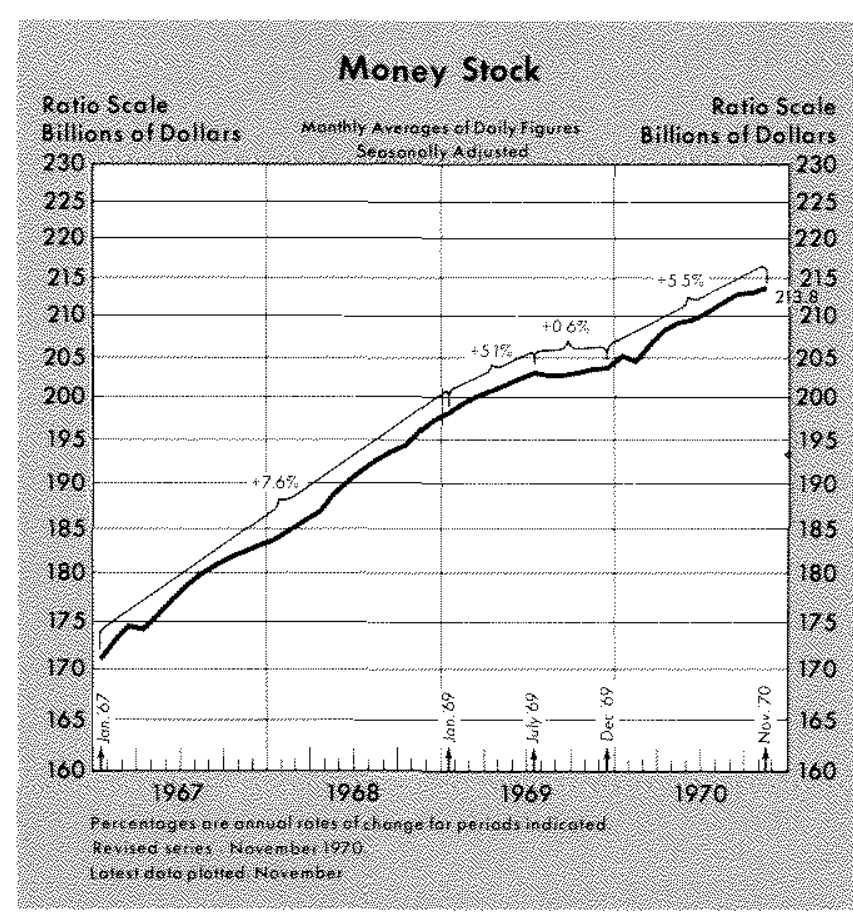

cent annual rate. This rate of increase was calculated on the basis of the revised series (November 1970) and was slightly faster than the rate calculated using the old series. Even though money grew on average at about the desired rate, the performance may have been accidental. From February to the four weeks ending June 17 , a period when there was an intensification of money market pressures and some interest rates rose, money expanded at a rapid 9 per cent annual rate. From the four weeks ending June 17 to the four weeks ending November 25, when money market conditions eased markedly and interest rates fell, money rose at a 3.7 per cent rate. This was similar to the previous promcyclical tendency of the System to inject money rapidly at times of huge credit demands (usually accompanying stronger business conditions), and to withdraw money or inject it slowly at times of weak credit demands (usually accompanying contractions in business activity). The pro-cyclical tendency of System actions when formulated in money market conditions terms was one reason for the System to shift to monetary aggregates in the formulation and implementation of monetary policy.

Studies at this bank indicate that temporary variations from trend, of the magnitude and duration of those experienced during 1970, have no significant effect on total spending, prices, production, or employment. If the deviations were larger or were allowed to persist longer, they would have undesirable results.
Money rose roughly 5 per cent in 1970 , based on quarterly averages of daily figures, increasing at annual rates of 4 per cent from the fourth quarter of 1969 to the first quarter of $1970,7.2$ per cent from the first to the second quarter, 5.3 per cent from the second to the third, and an estimated 4 per cent from the third to the fourth. During the Fifties and early Sixties, a 5 per cent growth of money was extraordinarily high and, if long maintained, tended to cause accelerating inflation. With the strongly imbedded inflation in 1970, however, spending could be permitted to expand faster than the growth of productive capacity and still place some downward pressure on prices. By permitting a growth in spending at a rate faster than in previous attacks on inflation, costs in terms of lost production and unemployment may be expected to be kept at relatively low levels.

Short-term interest rates declined sharply during 1970. There was a slowing in the demand for funds, reflecting a moderated growth in spending following from the monetary restraint of 1969 . Also, there were increasing supplies of short-term funds resulting from the more rapid injection of money during 1970 and from the temporary use of proceeds of long-term financing. Yields on prime 4- to 6-month commercial paper averaged $5 \%$ per cent in early December, down from 9 per cent in early January. The three-month Treasury bill rate was below 5 per cent in early December, compared with nearly 8 per cent at the beginning of the ycar. Reflecting the same forces, the rate charged prime business customers by commercial banks was lowered from $8^{1 / 2}$ per cent early in the year to 8 per cent in March, to $7^{1 / 2}$ per cent in September and to 7 per cent in November. The discount rate (the interest rate charged member banks by Reserve Banks) was out of touch with market rates early in the year, but as market rates declined markedly, the discount rate was reduced from 6 per cent to $5^{1 / 2}$ per cent in November and early December to keep it in line with other rates.

Long-term interest rates remained relatively high during 1970; mortgage rates changed little on balance while yields on municipal and Government securities declined from peak levels. Yjelds on highestgrade seasoned corporate bonds averaged about 7.8 per cent in early December, about the same as a year earlier. The continued high rates, despite some slowing in the growth of spending and presumably in overall credit demands, reflected in considerable measure the strongly imbedded inflationary expectations. With great inflationary expectations, incentives 
to borrow long are increased while incentives to lend at long term are reduced. Demands for long-term funds may also have been bolstered by an attempt to improve liquidity.

\section{Economic Developments in 1970}

Total spending on goods and services rose at a 4.6 per cent annual rate during the four quarters ending with the third quarter of 1970 , despite some large cutbacks in production of war goods. This was ap. proximately the growth in spending the St. Louis model had simulated given the monetary expansion which occurred. In the fourth quarter spending was interrupted by the major automobile strike, but much of the loss is expected to be made up within a few months after resumption of full production. By comparison spending rose at an excessive 8 per cent average rate from late 1964 to late 1969.

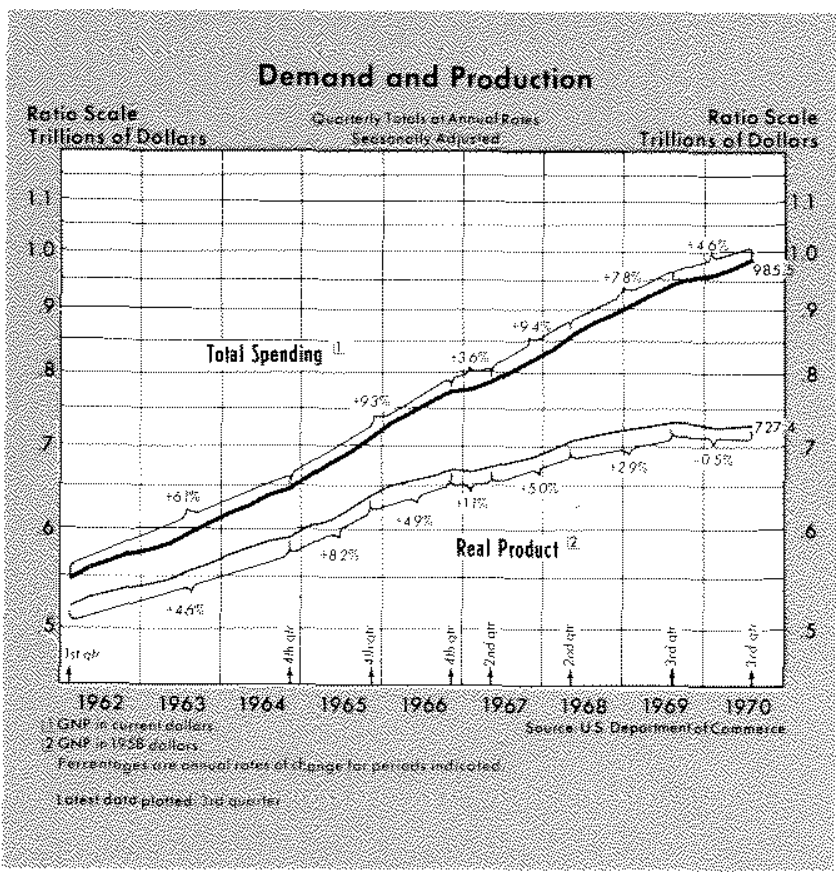

Government spending rose more rapidly than private spending in 1970. Federal Government expenditures rose at a 7.4 per cent annual rate in the first three quarters of the year, state and local government outlays expanded at an 11.1 per cent rate, and private spending increased at a 4.4 per cent rate. Defense outlays were reduced at a 5 per cent rate, while spending on all other programs of the Federal Government rose at a rapid 16 per cent rate.

Prices continued to rise in 1970 as a result of previous expansionary fiscal and monetary actions and consequent excessive total spending. However the acceleration of price increases was stopped early in 1970, and in the fall of the year signs became widespread that inflation was receding moderately. Prices of the sensitive thirteen raw industrial commodities have declined since early 1970 . Overall prices rose at a 4.4 per cent annual rate from the first to third quarter and probably continued to rise at approximately that pace in the fourth quarter. By comparison, these prices went up at a 5.3 per cent rate from late 1968 to early 1970. Consumer prices have risen at a 5 per cent rate since April, after increasing 6 per cent in the previous twelve months.

Hourly earnings in manufacturing, adjusted to exclude effects of overtime and interindustry shifts, have risen 6.6 per cent in the last twelve months. Adjusted for price increases, these earnings have increased about 1 per cent. When the value of fringe benefits is added, real eamings have probably increased more than estimated output per man hour. Nevertheless, these figures raise some doubt about the belief that the recent inflation has been the result primarily of a wage-push situation.

With prices rising about as fast as total spending, production was changed little on balance during the first three quarters of 1970 . There was a small net decine in the first quarter largely offset by slight rises in the second and third quarters. Production probably fell again in the final quarter of the year, but this was mainly the result of the automobile strike and probably did not reflect cyclical influences.

During 1970 the labor force grew, capital was invested, and there were advances in technology. As a result, productive capacity was rising while total output changed little on balance. Accordingly, resources not utilized or underutilized increased. Competition from these resources was the main force which tended to reduce the upward momentum of prices.

One indication of the utilization of capacity is provided by the employment rate. Employment declined from 95.8 per cent of the labor force in the first quarter of 1970 to about 94.5 per cent in the early Fall. Later in the year employment drifted a little lower in response to the interruption caused by the auto strike. In terms of married men, employment declined from 98 per cent early in the year to 97.1 per cent in the Fall.

All unemployment does not represent excess capacity. Workers leave jobs in search of better opportunities; some activities are seasonal; some people have but marginal production capacity; and some become 


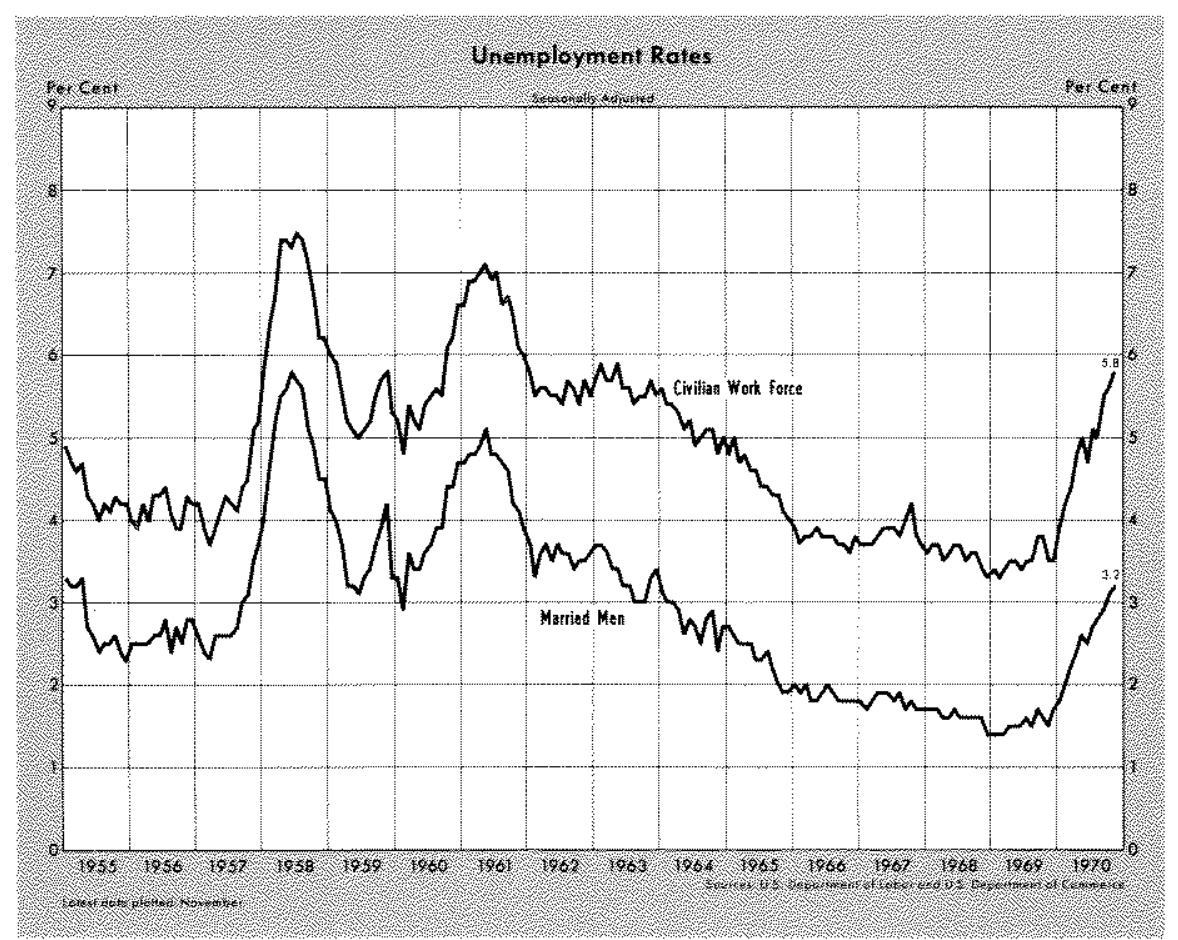

range. In the economic expansion between the 1958 and 1960 recessions, unemployment reached a low of 5 per cent. In 1958 and again in 1960 when downward pressure was applied to inflationary pressures, unemployment rose temporarily to 7 per cent and above. When unemployment remained below a 5 per cent rate in 1965 through 1969 , inflationary pressures intensified. Given minimum wage laws and other features of American labor markets, it may be that 5 per cent rather than-4 per cent or less unemployment is about the practical non-inflationary minimum. Attempts to maintain the unemployment rate at some artificially low level may succeed temporarily but ultimately will only assure accelerating inflation.

unemployed temporarily when businesses are forced to cut back or close because they are no longer competitive. Comparisons with previous periods may be helpful in evaluating the present unemployment rates. The recent 5.8 per cent rate of unemployment (including strike effects) compares with a 5.2 per cent rate in 1964, the last year of pronounced economic expansion without accelerating inflation. In 1962 and 1963 unemployment remained in the $5 \frac{1 / 2}{10} 6$ per cent

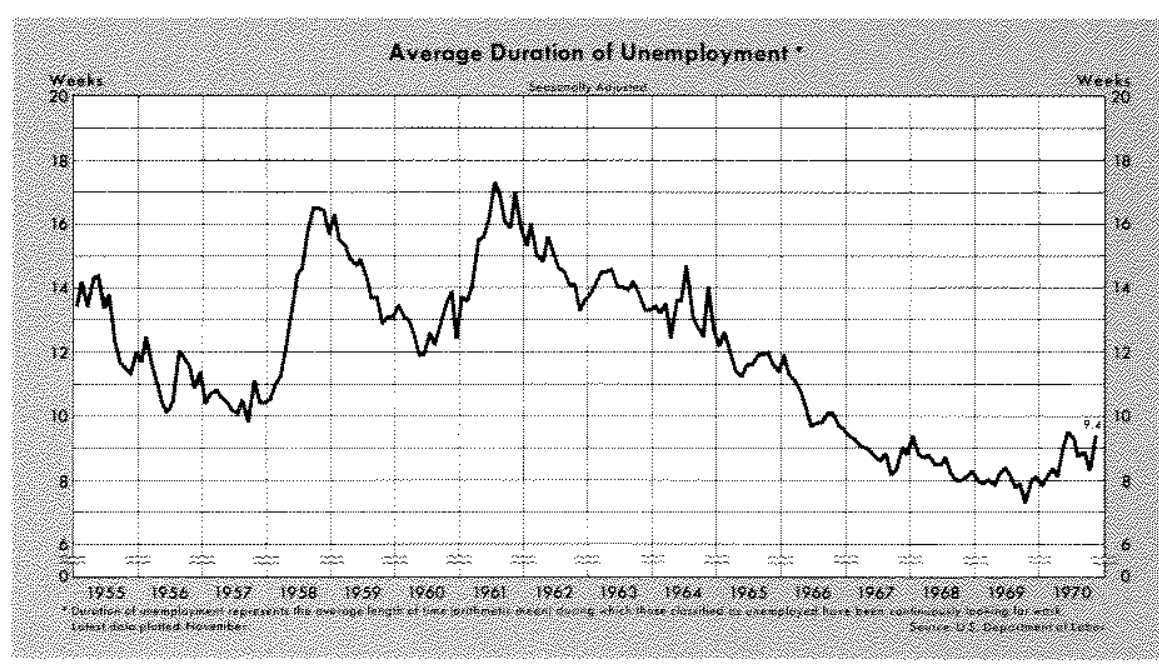

Tolol CWNicn Enploynent

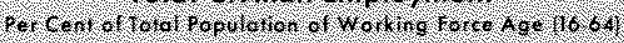

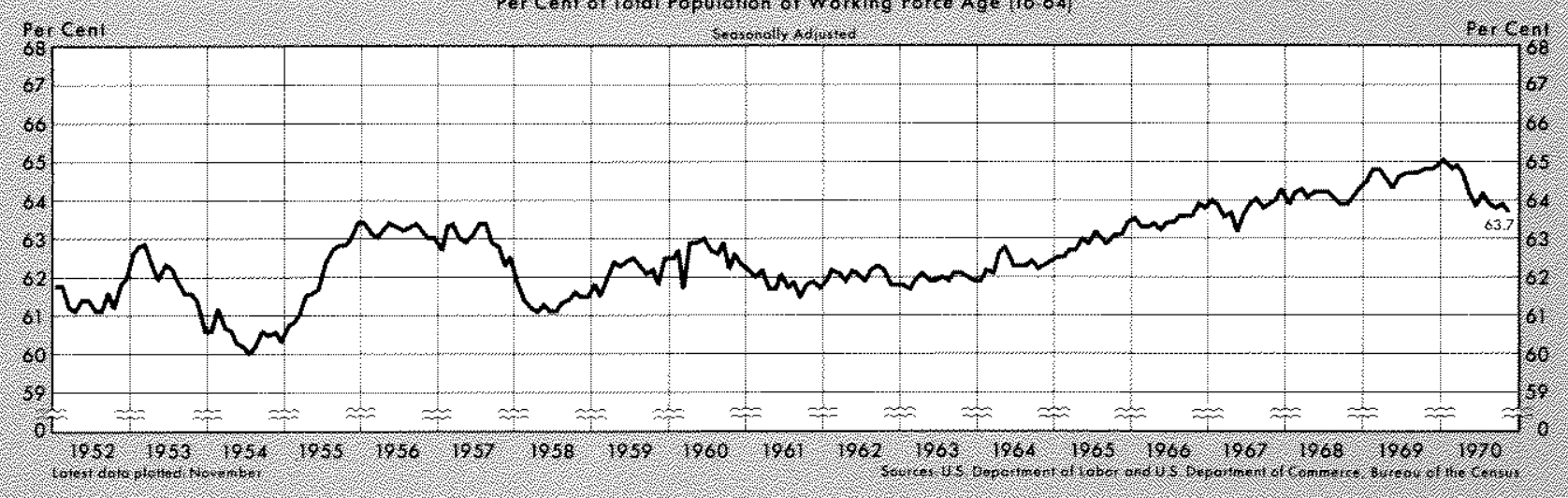

Page 10 
Another measure of the utilization of labor is the number of people actually working relative to the civilian population of working force age. The November level of 63.7 per cent is down from the peak, but still higher than anytime in the Fifities or Sixties before late 1966. Another indication of the magnitude of the employment situation is the duration of unemployment. This past fall the average length of unemployment was about 9 weeks, up from about 8 weeks in 1969, but still substantially below the 12 weeks or longer from 1958 to early 1965.

Corporate profits, after taxes, declined from a peak of $\$ 49.7$ billion in the second quarter of 1969 to $\$ 45.4$ billion in the third quarter of 1970 . Since the inflation began increasing in 1965, corporate profits have declined from 6.8 per cent of gross national product to 4.6 per cent.

\section{Policu Chobes for 1971}

As the new year begins, the critical question still remains, "How rapidly should the nation proceed in reducing inflation?" Prices are rising more slowly now than a year ago, and some further downward pressure has been accumulated that may be expected to reduce the inflation further in 1971. Even so, prices are likely to continue rising at a rather fast pace. At the same time, production is below capacity, some are unemployed, and the economy is sluggish.

The choice for the nation, as a year ago, is one of the lesser of evils. It serves no purpose to pretend there is an easy, costless, quick cure to inflation. The adverse consequences of the mistakes of $1965-68$ continue to bear heavily on the nation. To focus solely on either the inflation or the capacity utilization problem is apt to intensify the pain and suffering from the other. Some compromise has to be made. This Bank has again made simulations of prospective economic conditions, assuming various courses of monetary action. For the model simulations, Federal Government expenditures through second quarter of 1971 have been estimated by this Bank and have been projected thereafter to grow at an 8 per cent annual rate. The calculated figures were smoothed judgementally in the lower half of the table on page 12 to remove irregular fluctuations.

One course of action which might be followed would be to continue to seek a 5 per cent growth rate of money, the rate planned in the last-released record of policy actions. With such a growth of money, total spending growth might accelerate from the 4.5 per cent rate of the past year to about a 6.5 per cent rate in late 1971. If such a growth of money were maintained, spending might be expected to continue to grow at about the 6.5 per cent rate in the first half of 1972. Real output, which declined slightly in the past year, would probably be growing at about a 2.5 per cent rate a year from now. These simulations are designed only to project most probable cyclical and trend influences of money and the Federal budget on the economy. They do not purport to project erratic short-term developments, such as a bulge in spending and production after the auto strike and any dip in case of a steel strike.

The model indicates that with the 5 per cent growth of money, inflation would most likely still remain strong at the end of next year, with overall prices rising at about a 4 per cent annual rate. Recently, prices have been rising at about a 4.5 per cent pace. Unemployment would most likely move up from the recent 5.5 per cent of the labor force (excluding strike effects) to around a 6 per cent level.

If the nation desired a quicker approach to reducing inflation, a 2 per cent growth rate of money might be undertaken. The simulation indicates that spending under this policy might be down to about a 3.7 per cent growth rate a year from now. Inflation would be reduced slightly faster than with the 5 per cent rate of growth of money, dropping to about a 3.5 per cent rate a year from now and to about a 2.8 per cent rate by mid-1972. Production, however, would be very sluggish, and unemployment might rise to about 6.5 per cent of the labor force in late 1971 and to over 7 per cent by mid-1972. With unemployment at such a level, the temptation to restimulate the economy would become great regardless of inflationary consequences.

If it is desired to attempt to hold the adjustment costs in terms of lost production as low as possible in 1971 and early 1972 while placing some downward pressure on prices, a faster 8 per cent rate of money growth might be selected. In this case, model simulations indicate that spending might rise to about a 9.5 per cent growth rate in the Fall of next year and remain at that pace in the first half of 1972. Production would be rising at faster than an assumed 4 per cent long-term trend in late 1971 and in early 1972, and unemployment would probably not reach 6 per cent and would be declining in late 1971 and in early 1972. Prices, however, would continue to rise for a long, long time, since the rate of increase would be inching down very slowly. The total cost in lost pro- 
Toble 11

Current Projections of Total Spending, Real Product, Prices, Uhemployment, and, linterest Rates?

\begin{tabular}{|c|c|c|c|c|c|}
\hline & & & & & 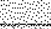 \\
\hline 11 & 14 & 11 & w & 1 & 11 \\
\hline ual & Estinated & & & & \\
\hline
\end{tabular}

Assurned Rates of Change in Money stouk

\section{Per Cent}

Annual Rote of Change in:

Nominal GNP

Real eNP

GNP Pilce Deflator

Unemploynenl Rate

Corporate Aar Relte

\section{5. per cent}

Annuat Rote of Chonge in? Nominal GNP

Real GNP

Ghep rice Deforo

Uhemploynent Rote

Corporate Aac Rale

8 per cent

Antulal Rate of Change in:

Noninal GKP

Real GMP

GNP Price Denctor

Unemplownent rate

Corporicte Aad Rate
AS GENERATED DIRECTYY BY THE ST. LOUIS MODEL

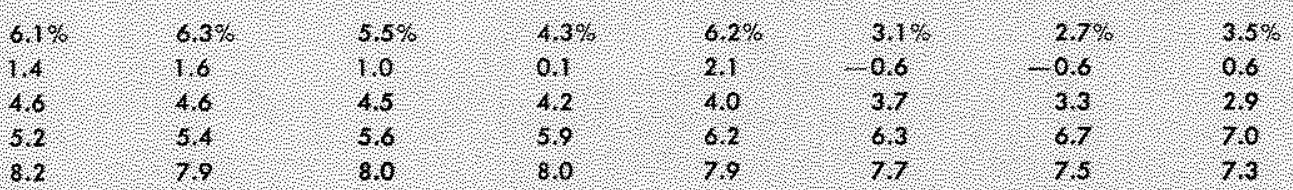

61

14

46

6.2

0,2
6

16

46

5.4

120

5,6

\section{1}

1,7

4,3

3.8

79

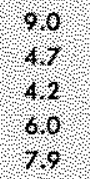

6.6

23

40

60

72

\begin{tabular}{|c|c|}
\hline 178 & 118 \\
\hline 3.4 & 73 \\
\hline 44 & 43 \\
\hline 57 & 58 \\
\hline 78 & $7 \%$ \\
\hline
\end{tabular}

9.6
5,3
5.6
7

409

46

42

5,5

76

5.6
2.0
3.0
6.1
7.6

\section{AS SMOOTHED TO REMOVE IRREGULAR FLUCTUATIONS}

2 Per cent

Annual Role of Change in. Nominal GNP

$5.6 \% \%$

$6.0 \%$
4.6
5.4

$5.7 \%$
4.5
5.6

$4.8 \%$

0.6

GNP Erice Deflotor

4,7

5.2.

5.4

Corporate Aaa Rate

8.2

80

50

59

80

$4.1 \%$
0.1
4.0
7.9

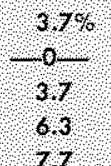

$3.6 \%$

0.3

3.3

67

5 Per cent

Annual rate of change int Nominal GNP

Real GWP

GNP Price Deflator

\section{6}

0.9

6.0
1.4
4.6
7.4
7.9

6.3
1.8
4.5
7.6

6.4
2.1
4.8
70

6.5
2.3
4.2
5.9
7.8

6.5
2.5
4.0
6.0
7.7

6.5

t,

3.8

6.1

7,6

Comportete had Rate.

82

\section{Per Cent}

Annual Rave of Change in. Nonitnal GNIP

Real GNP:

GNP Price Deflator

Unemployment Rate?

Corporate Aad Rate

\begin{tabular}{|c|c|c|}
\hline 5.6 & 60 & 72 \\
\hline 09 & 1,4 & 27 \\
\hline 47 & 46 & 4.5 \\
\hline 32 & 5.4 & 5.6 \\
\hline 82 & 79 & 7.7 \\
\hline
\end{tabular}

\begin{tabular}{|c|c|}
\hline 8.5 & 9,5 \\
\hline 41 & 6.2 \\
\hline 4.4 & 43 \\
\hline 57 & 5,8 \\
\hline 78 & 78 \\
\hline
\end{tabular}

95
5,3
5
5

9.5
5,3
4.5

96

5.5

41

3,4

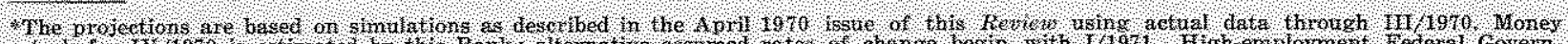

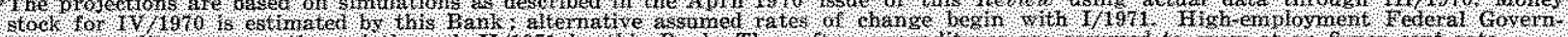

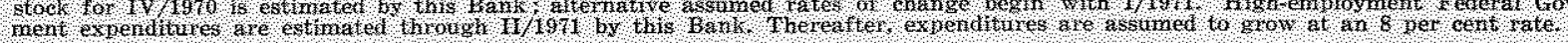


duction might be as great or greater under this course, if price stability is ever to be achieved, as it would be under a more aggressive approach, since actions to dampen inflation would have to be continued much longer.

\section{Conclusions}

Inflation in recent years has been one of the nation's most serious domestic economic problems. It causes inequities and inefficiencies, and prejudices the future viability of the economic system. The process of its elimination is inevitably causing an underutilization of labor and other resources. The first effective steps in eliminating the inflationary mistakes of 1965-68 were taken by the monetary authorities in 1969, yet price increases continuted unabated throughout that year. Monetary actions were relaxed in early 1970 but have continted to be anti-inflationary. During 1970 the rate of inflation began ebbing, with overall prices rising at an estimated 4.5 per cent rate now, compared with a 5.5 per cent rate a year ago.

The transition to a lower rate of inflation has been painful for many. Real product has increased little, if at all, and contracts based on expected continued rapid inflation are costly to fulfill. Yet, given the strongly imbedded inflation, the costs of reducing it have not been so great as one might have anticipated from previous attempts at arresting inflation in this country. Studies at this Bank indicate that the cutbacks in prodtuction and employment in the 1969-70 battle against inflation were smaller because the nation's money stock was not permitted to decline, as it did in previous periods of correction. Since early 1969 money has expanded at an average 4 per cent annual rate.

Simulations using the Bank's model indicate that if money continues to rise moderately, further progress will be made in 1971 in reducing the pace of price increases. However, the battle will not be won easily and without cost. Expectations of rising prices are still strong. Some prices, such as those in term contracts and union wages, were relatively inflexible during the excessive spending of the late 1960's. Other prices were temporarily held back by inertia, a money illusion, lack of knowledge of costs, public opinion and Government regulation. As these wages and prices now move toward equilibrium levels, the increased production costs place upward pressure on other prices.

Some believe that prices and wages could be held stable with much less cost by merely "controlling" them. It seems so simple to just have the Government outlaw inflation. Suggestions have taken a variety of forms from a broadscale rigid control of all prices, with severe penalties for violations, to a temporary freeze, to a control of certain key prices, and even to using persuasive tactics called "jawboning." Yet, past attempts to control prices both here and abroad indicate that such controls have been largely ineffective. Controls are frequently circumverted through blackmarkets, quality deterioration, clever pricing, or other devices. Controls are costly to adminster, impinge on freedom, create shortages (usually requiring rationing), misallocate resources, and frequently slow the rate of economic growth.

A contribution can be made to a more rapid solution of the problems of inflation and underutilization of capacity by improving the market system. Such actions might include reducing subsidies, tariffs and import quotas, widening the scope of the anti-trust laws to cover more monopolistic practices, increasing the skills of workers, eliminating outdated building codes and other barriers to greater productivity, and modifying the minimum wage laws in the interest of improving job opportunities for teenagers and the handicapped.

Progress has been made on the inflation problem. Costs have occurred in reducing it, but so far they have been less than in any previous attempt. Continued perseverance along the general course charted in the past two years would seem to be appropriate in 1971. As long as total spending continues to grow at a moderated rate, both the inflation and the capacity utilization problems will be gradually solved as the effects of past maladjustments atrophy. Experience demonstrates that Government actions designed to shock the economy into a quicker adjustment have usually had net adverse consequences. 